\title{
Impacts of the Fukushima nuclear accident on the China Seas: Evaluation based on anthropogenic radionuclide ${ }^{137} \mathrm{Cs}$
}

\author{
WU JunWen, ZHOU KuanBo \& DAI MinHan* \\ State Key Laboratory of Marine Environmental Science, Xiamen University, Xiamen 361005, China
}

Received March 9, 2012; accepted July 10, 2012; published online September 27, 2012

In order to evaluate the impact of the Fukushima nuclear accident on the China Seas, seawater samples from the South China Sea (SCS), the East China Sea (ECS) and the Yellow Sea (YS) were collected in April-June 2011, and their ${ }^{137}$ Cs activities were measured using low-background $\gamma$-spectrometry. ${ }^{137} \mathrm{Cs}$ activities in the study area ranged from $0.75 \pm 0.07$ to $1.43 \pm 0.08 \mathrm{~Bq} \mathrm{~m}^{-3}$ with an average of $1.12 \pm 0.08 \mathrm{~Bq} \mathrm{~m}^{-3} \cdot{ }^{137} \mathrm{Cs}$ activities initially increased from the nearshore to the inner shelf, and subsequently decreased from the inner shelf to the outer shelf. Vertical profiles showed higher ${ }^{137} \mathrm{Cs}$ activities at the surface but lower activities at depth in the ECS, suggesting atmospheric input of ${ }^{137} \mathrm{Cs}$. As such, the distribution pattern of ${ }^{137} \mathrm{Cs}$ in the region was presumably determined by a combination of atmospheric deposition and subsequent mixing between different water masses including the coastal currents, the Yangtze River plume and the Taiwan Warm Currents. Based on the inventory of $93 \mathrm{~Bq} \mathrm{~m}^{-2}$ and the atmospheric deposition flux of ${ }^{137} \mathrm{Cs}$ in the ECS of $32.2 \mathrm{mBq} \mathrm{m}^{-2} \mathrm{~d}^{-1}\left(5.4-42.9 \mathrm{mBq} \mathrm{m}^{-2} \mathrm{~d}^{-1}\right)$ which we estimated, we derived the residence time of ${ }^{137} \mathrm{Cs}$ in the upper water column to be $66 \mathrm{~d}(45-95 \mathrm{~d})$. We concluded that in terms of ${ }^{137} \mathrm{Cs}$, the ECS was less impacted by the Fukushima accident as compared to the Chernobyl accident. The released amount of ${ }^{137} \mathrm{Cs}$ into the ECS from the Fukushima accident was minute.

Fukushima nuclear accident, anthropogenic radionuclide, ${ }^{137} \mathrm{Cs}$, radioactive contamination, China Seas, atmospheric deposition

Citation: Wu J W, Zhou K B, Dai M H. Impacts of the Fukushima nuclear accident on the China Seas: Evaluation based on anthropogenic radionuclide ${ }^{137}$ Cs. Chin Sci Bull, 2013, 58: 552-558, doi: 10.1007/s11434-012-5426-2

The Fukushima nuclear accident, which was associated with a magnitude 9.0 earthquake and the subsequent tsunami occurred on 11 March, 2011, and released a large amount of artificial radioactive fission products, including ${ }^{131} \mathrm{I},{ }^{134} \mathrm{Cs}$, ${ }^{137} \mathrm{Cs},{ }^{239} \mathrm{Pu}$ and ${ }^{240} \mathrm{Pu}$ from the nuclear reactors into the environment via immediate discharge into the ocean and rapid dispersal into the atmosphere [1]. Using a regional ocean circulation model, Tsumune et al. [2] estimate that a total of $3.5 \pm 0.7 \mathrm{PBq}\left(1 \mathrm{PBq}=10^{15} \mathrm{~Bq}\right)$ of ${ }^{137} \mathrm{Cs}$ was directly discharged to the ocean from 26 March to 30 May, 2011. Buesseler et al. [3] further assess the impacts of the accident on the marine environment based on a field survey from 4 to 18 June, 2011, and reveal that the ${ }^{137} \mathrm{Cs}$ activities and inventories markedly increased in the ocean waters sur-

*Corresponding author (email: mdai@xmu.edu.cn) rounding Fukushima. In addition to this direct release into the ocean, the accident also dispersed about $15 \mathrm{PBq}$ of ${ }^{137} \mathrm{Cs}$ to the atmosphere, dominated by a leak from 12 March to 6 April, 2011 [4]. These nuclides once discharged into the atmosphere might have a global effect through fast atmospheric circulation. Indeed, ${ }^{133} \mathrm{Xe}$, a typical nuclear fission product was observed on 16 March, 2011 at the US Pacific Northwest National Laboratory $\left(46.28^{\circ} \mathrm{N}, 119.28^{\circ} \mathrm{E}\right)$, which is located more than $7000 \mathrm{~km}$ from Fukushima [5]. Meanwhile, elevated ${ }^{131} \mathrm{I},{ }^{134} \mathrm{Cs}$ and ${ }^{137} \mathrm{Cs}$ activities in both air and rainwater samples were detected from 24 March to 9 April, 2011 at Thessaloniki, Greece $\left(40.63^{\circ} \mathrm{N}, 22.97^{\circ} \mathrm{E}\right)$ [6], which is located more than $7500 \mathrm{~km}$ from Fukushima.

The China Seas are located in the Northwest Pacific Ocean. It might have been difficult for the materials released immediately off Fukushima to be transported into the 
China Seas due to the strong west boundary ocean currentKuroshio, which flows northeastwardly along the boundary off the China Seas. Atmospheric deposition was thus thought to be the main introduction route for the nuclides released into the China Seas. Based on the Weather Research and Forecasting/Chemistry tracer model, Huh et al. [7] simulated the transport of the nuclides in the planetary boundary layer by the northeast monsoon wind directly toward the China Seas, which was further validated by the field observation data collected at Pengchiayu (PCY, $25.62^{\circ} \mathrm{N}$, $122.07^{\circ} \mathrm{E}$ ) in the ECS. The first plume observed at PCY was on 25 March with an activity level of ${ }^{137} \mathrm{Cs}$ at $0.0068 \pm$ $0.0022 \mathrm{mBq} \mathrm{m}^{-3}$ and of ${ }^{134} \mathrm{Cs}$ at $0.0062 \pm 0.0011 \mathrm{mBq} \mathrm{m}^{-3}$. On 6 April the ${ }^{137} \mathrm{Cs}$ levels peaked at $1.4411 \pm 0.0209 \mathrm{mBq} \mathrm{m}^{-3}$ and ${ }^{134}$ Cs peaked at $1.1235 \pm 0.0175 \mathrm{mBq} \mathrm{m}^{-3}$ [7].

This study sought to examine how significantly the Fukushima incident impacted on the marine environment in the China Seas, especially in the ECS. We report for the first time the activity level and distribution pattern of ${ }^{137} \mathrm{Cs}$ in the China Seas after the Fukushima nuclear accident. We show that the elevation of ${ }^{137} \mathrm{Cs}$ activities and inventory in the ECS during our investigation period were minor as compared to those prior to the accident, suggesting that the China Seas were not significantly impacted by the Fukushima accident.

\section{Materials and methods}

Seawater samples for ${ }^{137} \mathrm{Cs}$ were collected at nine selected stations, six in the ECS, two in the South China Sea (SCS) and one in the Yellow Sea (YS), during a cruise to the China Seas from 29 April to 13 June, 2011 (Figure 1). Surface samples (about $50 \mathrm{~L}$ each) were pumped directly into plastic buckets and subsurface samples were collected from Niskin bottles on a CTD rosette system. Upon collection, samples were acidified with concentrated $\mathrm{HNO}_{3}$ to $\mathrm{pH}<2$. A stable $\mathrm{Cs}^{+}$carrier $(\mathrm{CsCl}$ solution) was added and continuously stirred for $\sim 30 \mathrm{~min}$, and then an aliquot of ammonium molybdophosphate (AMP) was added and stirred again for $\sim 2 \mathrm{~h}$. After standing for 18-24 h, the supernatant was siphoned off and the precipitate was filtered on a quantitative membrane filter. Finally, the AMP/Cs precipitates were dried and placed into a plastic container before gamma counting. Aoyama et al. [8] describe the detailed analytical procedures for low level ${ }^{137} \mathrm{Cs}$ measurements in seawater. The ${ }^{137} \mathrm{Cs}$ activities on AMP/Cs were measured using GC4020 $\gamma$-spectrometry with high-purity germanium detectors specially designed for low-background counting and located at the Third Institute of Oceanography, State Oceanic Administration. The average detection efficiency and detection limit of GC4020 $\gamma$-spectrometry were $5.0 \%$ and $0.25 \mathrm{~Bq} \mathrm{~m}^{-3}$ (95\% confidence level), respectively. The chemical yields and final errors of ${ }^{137} \mathrm{Cs}$ were $94.8 \pm 1.4 \% \mathrm{SD}$ and $7.5 \pm 1.6 \%$ $\mathrm{SD}$, respectively.

\section{Results and discussion}

\section{1 ${ }^{137}$ Cs activities in the China Seas}

Analytical results for ${ }^{137} \mathrm{Cs}$ activities and the related information in the China Seas are presented in Table 1. During our observation period, ${ }^{137} \mathrm{Cs}$ activities in the China Seas showed small variations ranging from $0.75 \pm 0.07$ to $1.43 \pm$ $0.08 \mathrm{~Bq} \mathrm{~m}^{-3}$, with an average of $1.12 \pm 0.08 \mathrm{~Bq} \mathrm{~m}^{-3}(n=11)$. In detail, the averages of ${ }^{137} \mathrm{Cs}$ activities in the surface seawater were $1.10 \pm 0.07 \mathrm{~Bq} \mathrm{~m}^{-3}(n=1)$ in the YS, $1.10 \pm 0.09$ $\mathrm{Bq} \mathrm{m}^{-3}\left(0.75 \pm 0.07-1.43 \pm 0.08 \mathrm{~Bq} \mathrm{~m}^{-3}, n=6\right)$ in the ECS, $1.28 \pm 0.08 \mathrm{~Bq} \mathrm{~m}^{-3}\left(1.14 \pm 0.06-1.41 \pm 0.09 \mathrm{~Bq} \mathrm{~m}^{-3}, n=2\right)$ in the SCS. Such activity ranges were lower than the Chinese seawater quality standard $\left(700 \mathrm{~Bq} \mathrm{~m}^{-3}\right)$ and the Japanese regulatory limits for the ocean $\left(90000 \mathrm{~Bq} \mathrm{~m}^{-3}\right)$, and were also below the levels of the most abundant natural radionuclide in the ocean, ${ }^{40} \mathrm{~K}\left(\sim 12000 \mathrm{~Bq} \mathrm{~m}^{-3}\right)$ [3]. At present, ${ }^{137} \mathrm{Cs}$ activities in the China Seas are also lower compared to other marginal seas. For example, ${ }^{137} \mathrm{Cs}$ activities in the surface water of the Japan Sea were $2.7 \mathrm{~Bq} \mathrm{~m}^{-3}(1.0-4.4 \mathrm{~Bq}$ $\left.\mathrm{m}^{-3}, n=109\right)$ during 1991-2000 [11], and in the Okhotsk Sea were $1.9 \mathrm{~Bq} \mathrm{~m}^{-3}\left(1.7-2.1 \mathrm{~Bq} \mathrm{~m}^{-3}, n=4\right)$ in 1995 [12]. Such higher ${ }^{137} \mathrm{Cs}$ activities in those seas could have been induced by the dumping of radioactive waste by the Russian Federation and the former Soviet Union [13]. In addition, to examine if ${ }^{137} \mathrm{Cs}$ activities have a regional difference in the China Seas, we applied a simple $F$-test and $T$-test. The results suggested no significant difference $(P=0.416)$, which may be associated potentially with the homogenous deposition rate of ${ }^{137} \mathrm{Cs}$ over the surface.

\subsection{Distribution of ${ }^{137} \mathrm{Cs}$ in the China Seas}

(i) Horizontal distribution. The spatial distribution of ${ }^{137} \mathrm{Cs}$ activities in the surface seawater of the China Seas are shown in Figure 2. Because of the scarce data collected in the YS and SCS, here we focused the ${ }^{137}$ Cs distribution and its controlling factors on the ECS. Figure 2(b) makes it clear that the ${ }^{137} \mathrm{Cs}$ activities increased from the nearshore to the inner shelf and subsequently decreased from the inner shelf to the outer shelf, the pattern presumably determined by a combination of atmospheric deposition and mixing between different water masses. On the one hand, according to Hsu et al. [14], ${ }^{137} \mathrm{Cs}$ in the atmosphere and derived from Fukushima should be transported from the outer shelf to the nearshore under the prevailing north-easterly winds in the ECS. If only considering atmospheric deposition, the ${ }^{137} \mathrm{Cs}$ activities should gradually have decreased from the outer shelf to the nearshore, which is not consistent with our field observations. On the other hand, according to hydrological observation in the ECS from May to June, 2011, station PN05 was affected by the Yangtze River plume and the Taiwan Warm Currents, station DH51 was also affected by coastal currents (Liu et al., unpublished data). Combining 


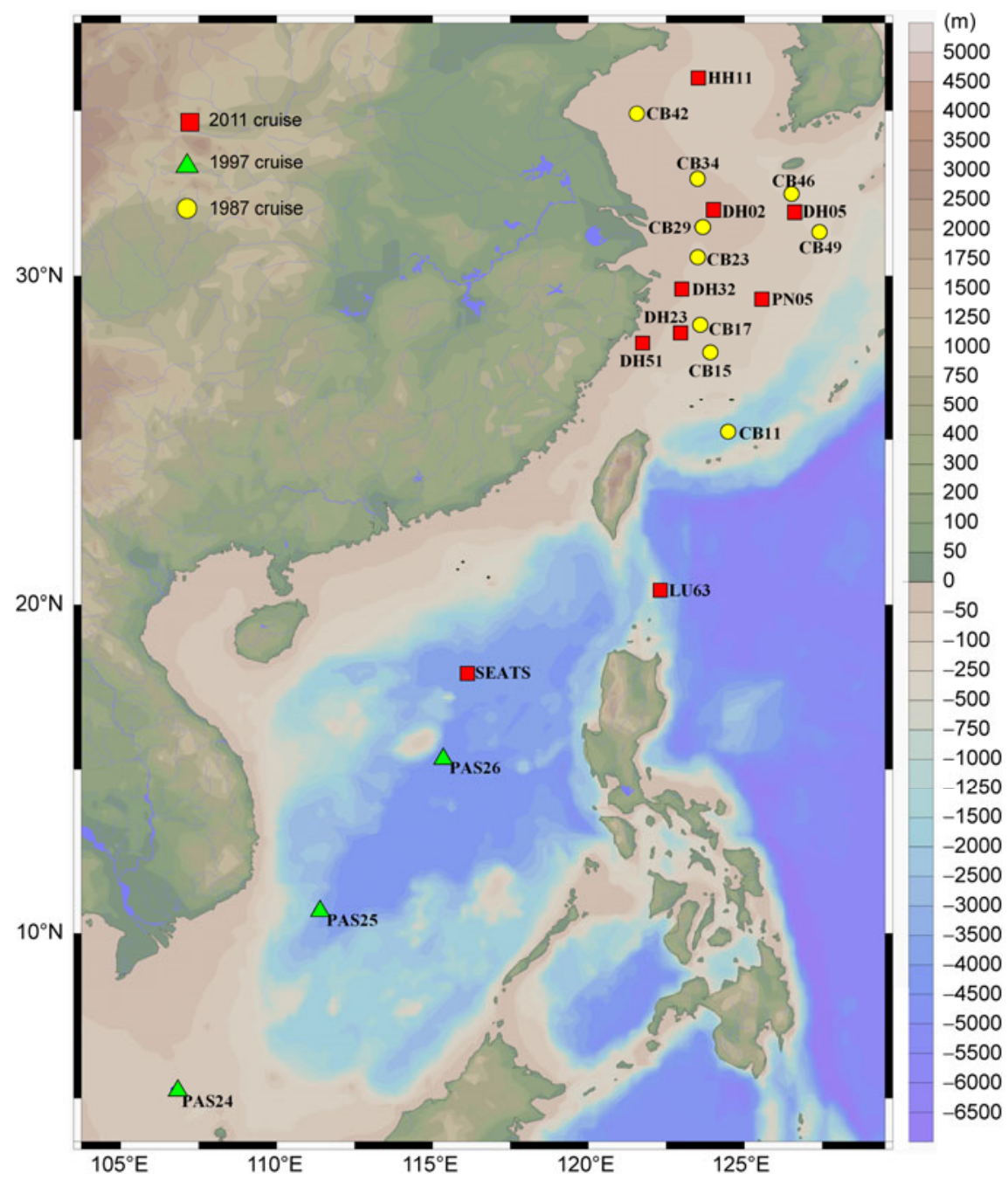

Figure 1 Map showing locations of sampling stations in the China Seas. Red squares represent sampling stations of this study conducted during a 2011 cruise, the yellow circles indicate sampling conducted in a 1987 cruise [9], and the green triangles represent samples collected during a 1997 cruise [10].

Table $1{ }^{137}$ Cs activities of seawater in the China Seas ${ }^{\text {a) }}$

\begin{tabular}{|c|c|c|c|c|c|c|c|c|c|}
\hline Area & Station & Latitude $(\mathrm{N})$ & Longitude (E) & Sample date & Depth (m) & $\begin{array}{l}\text { Sample depth } \\
(\mathrm{m})\end{array}$ & $\begin{array}{c}\text { Temperature } \\
\left({ }^{\circ} \mathrm{C}\right)\end{array}$ & Salinity & $\begin{array}{c}{ }^{137} \mathrm{Cs}^{\mathrm{b})} \\
\left(\mathrm{Bq} \mathrm{m}^{-3}\right)\end{array}$ \\
\hline YS & HH11 & $36.048^{\circ}$ & $123.498^{\circ}$ & 2011-06-08 & 77 & 0.5 & 15.836 & 31.890 & $1.10 \pm 0.07$ \\
\hline \multirow{8}{*}{ ECS } & DH02 & $31.999^{\circ}$ & $123.999^{\circ}$ & 2011-06-07 & 43 & 0.5 & 16.610 & 31.404 & $1.32 \pm 0.10$ \\
\hline & DH05 & $32.006^{\circ}$ & $126.481^{\circ}$ & 2011-06-07 & 102 & 0.5 & 19.592 & 33.382 & $1.01 \pm 0.06$ \\
\hline & DH32 & $29.643^{\circ}$ & $123.038^{\circ}$ & 2011-06-02 & 62 & 0.5 & 21.931 & 33.652 & $1.31 \pm 0.13$ \\
\hline & PN05 & $29.336^{\circ}$ & $125.521^{\circ}$ & 2011-06-06 & 102 & 0.5 & 20.450 & 32.051 & $0.75 \pm 0.07$ \\
\hline & DH51 & $27.880^{\circ}$ & $121.676^{\circ}$ & $2011-05-31$ & 36 & 0.5 & 20.340 & 31.333 & $0.80 \pm 0.08$ \\
\hline & DH23 & $28.331^{\circ}$ & $123.006^{\circ}$ & 2011-06-01 & 77 & 0.5 & 22.536 & 34.129 & $1.43 \pm 0.08$ \\
\hline & DH23 & $28.331^{\circ}$ & $123.006^{\circ}$ & 2011-06-01 & 77 & 50 & 18.738 & 34.169 & $1.20 \pm 0.10$ \\
\hline & DH23 & $28.331^{\circ}$ & $123.006^{\circ}$ & 2011-06-01 & 77 & 75 & 18.214 & 34.482 & $0.84 \pm 0.07$ \\
\hline \multirow{2}{*}{ SCS } & LU63 & $20.500^{\circ}$ & $122.290^{\circ}$ & 2011-05-05 & 3417 & 0.5 & 28.153 & 34.233 & $1.14 \pm 0.06$ \\
\hline & SEATS & $18.000^{\circ}$ & $116.000^{\circ}$ & 2011-05-08 & 3846 & 0.5 & 27.570 & 33.705 & $1.41 \pm 0.09$ \\
\hline Min & & & & & & & 15.836 & 31.333 & $0.75 \pm 0.07$ \\
\hline Max & & & & & & & 28.153 & 34.482 & $1.43 \pm 0.08$ \\
\hline Average & & & & & & & 20.906 & 33.130 & $1.12 \pm 0.08$ \\
\hline
\end{tabular}

a) The ${ }^{137} \mathrm{Cs}$ activities were decay-corrected back to the date of collection; b) the errors quoted for ${ }^{137} \mathrm{Cs}$ activities are $1 \sigma$ values derived from counting statistics. 

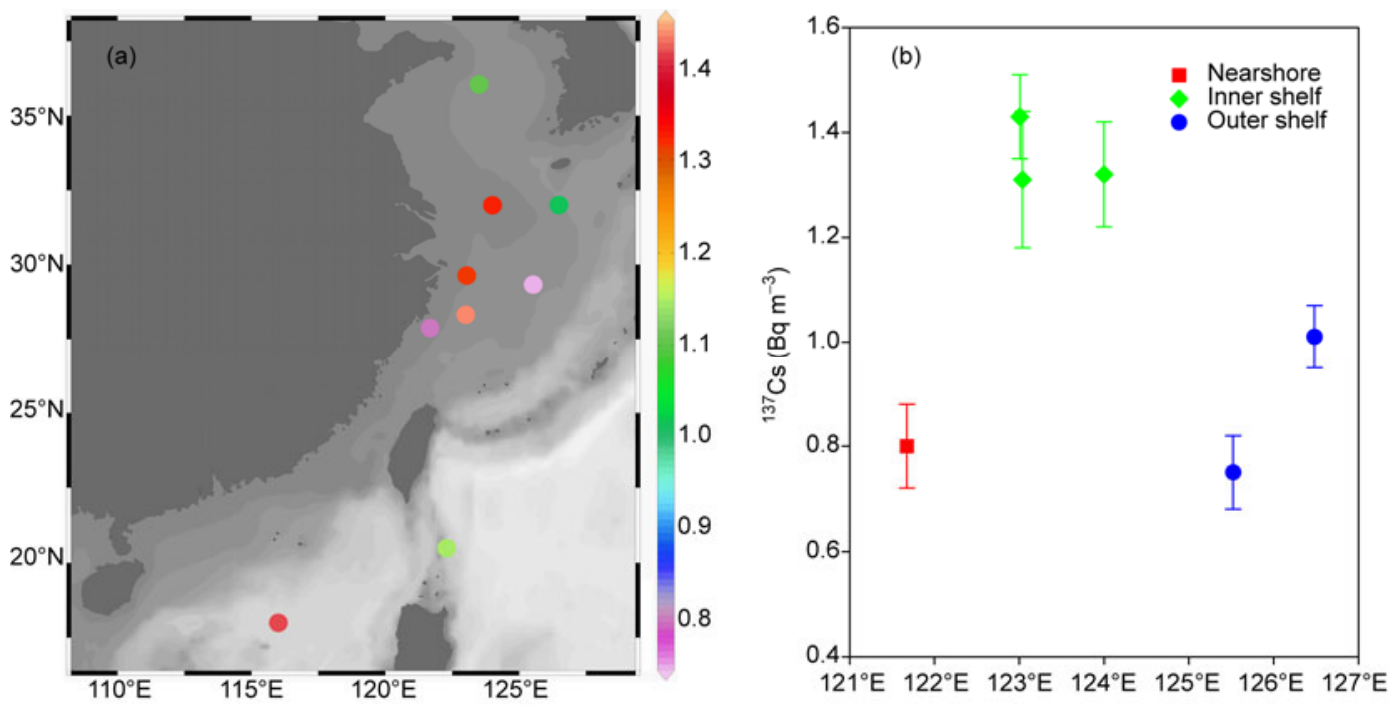

Figure 2 The horizontal distribution of ${ }^{137} \mathrm{Cs}$ activities in the surface water of the China Seas (a). Also shown is the plot of ${ }^{137} \mathrm{Cs}$ activities against longitude in the East China Sea (b).

the surface current pattern in the ECS [15] with the relationship between salinity and ${ }^{137} \mathrm{Cs}$ activity, we identified the factors influencing ${ }^{137} \mathrm{Cs}$ distribution in the ECS, e.g. in station DH51 influenced by the Min-Zhe Coastal Currents, in station PN05 influenced by both the Yangtze River plume and the Taiwan Warm Currents, and in station DH05 influenced by atmospheric deposition and the Taiwan Warm Currents. This suggested that ${ }^{137} \mathrm{Cs}$ distribution in the surface water of the ECS was controlled by both atmospheric deposition and water mass movement.

(ii) Vertical distribution. The vertical profile of ${ }^{137} \mathrm{Cs}$ activities along with T-S (temperature-salinity) in the ECS is shown in Figure 3 . The ${ }^{137} \mathrm{Cs}$ activities from surface to bottom ranged from $0.84 \pm 0.07$ to $1.43 \pm 0.08 \mathrm{~Bq} \mathrm{~m}^{-3}$. The temperature was $18.195-22.768^{\circ} \mathrm{C}$ and the salinity $34.043-$ 34.484. The consistent T-S characteristics suggested that the shallow water column (down to $18 \mathrm{~m}$ ) or that below $60 \mathrm{~m}$ were uniform. The depth profile of ${ }^{137} \mathrm{Cs}$ activities showed a maximum in the surface water and decreased gradually with depth. The high ${ }^{137} \mathrm{Cs}$ activities of the surface water might have been induced by the atmospheric deposition after the Fukushima accident, and it was then decreased with depth due to mixing and/or dilution with the low ${ }^{137} \mathrm{Cs}$ deep water. Thus, the vertical pattern of ${ }^{137} \mathrm{Cs}$ in station $\mathrm{DH} 23$ was representative of the ECS. It is worth mentioning that such a profile pattern for ${ }^{137} \mathrm{Cs}$ in station DH23 was indeed similar to those commonly observed in the Northwest Pacific Ocean [16-18].

\subsection{Impact of ${ }^{137}$ Cs derived from the Fukushima nuclear accident}

(i) ${ }^{137} \mathrm{Cs}$ inventories and residence times. An inventory of ${ }^{137} \mathrm{Cs}$ is a useful indicator for assessing its accumulation process in the ocean. The inventory of ${ }^{137} \mathrm{Cs}$ in the water

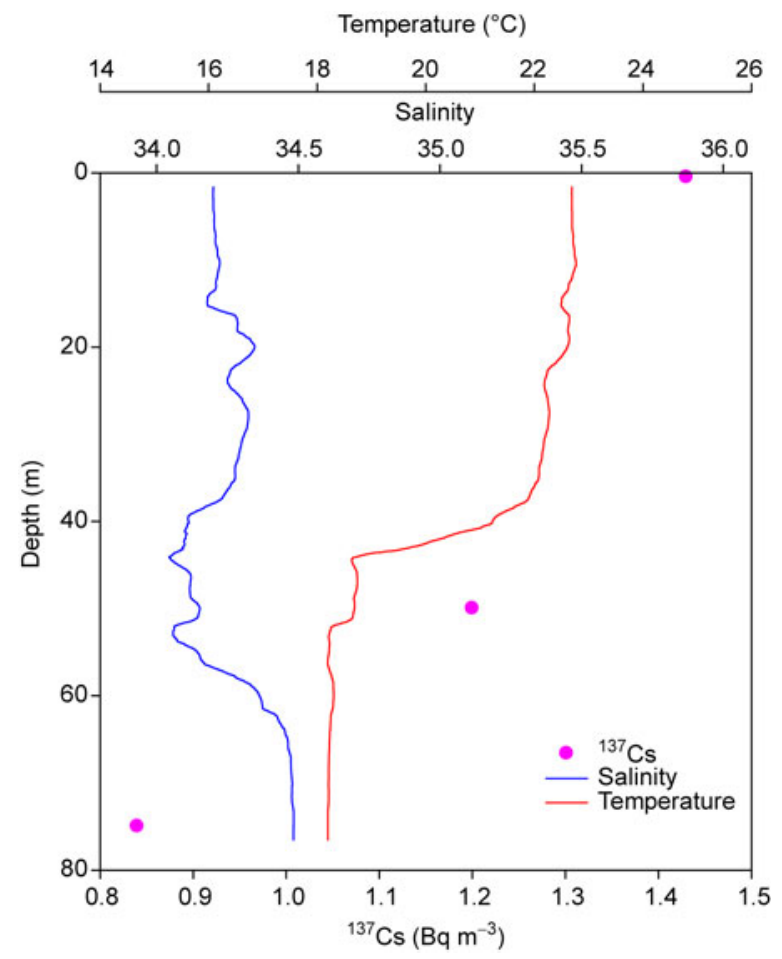

Figure 3 Vertical profiles of ${ }^{137} \mathrm{Cs}$ activities, temperature and salinity at station DH23 in the East China Sea.

column is calculated by integrating the activity measured at each depth [19]. We calculated the ${ }^{137} \mathrm{Cs}$ inventory for comparison with preexisting ${ }^{137} \mathrm{Cs}$ inventories in the ECS (Table 2). After the Fukushima nuclear accident, the ${ }^{137} \mathrm{Cs}$ inventory of seawater was calculated as $93 \mathrm{~Bq} \mathrm{~m}^{-2}$, while the ${ }^{137} \mathrm{Cs}$ inventories of seawater after the Chernobyl accident were $131-3288 \mathrm{~Bq} \mathrm{~m}^{-2}$ [9]. It was noted that the ${ }^{137} \mathrm{Cs}$ inventory in station CB17 near our station DH23 was 2 times greater, which indicated a significantly lower input of 
${ }^{137}$ Cs by the Fukushima accident compared to the Chernobyl accident if we assumed that the ${ }^{137} \mathrm{Cs}$ levels were identical in the ECS prior to the Fukushima and Chernobyl accidents.

${ }^{137} \mathrm{Cs}$ is a highly seawater soluble radionuclide $(<1 \%$ is attached to marine particles) with conservative behavior [20]. If we assumed that ${ }^{137} \mathrm{Cs}$ in the ECS was derived only from atmospheric fallout and that its vertical mixing followed the one dimensional diffusion model, the input flux of ${ }^{137} \mathrm{Cs}$ from surface to bottom could be calculated by combining the ${ }^{137} \mathrm{Cs}$ activity gradient with the vertical diffusion coefficient. In station $\mathrm{DH} 23$, the ${ }^{137} \mathrm{Cs}$ activity gradient was calculated as $-0.0074 \mathrm{~Bq} \mathrm{~m}^{-3} \mathrm{~m}^{-1}$, and the vertical diffusion coefficients in the ECS are $22.0 \mathrm{~cm}^{2} \mathrm{~s}^{-1}(15.3-32.4$ $\mathrm{cm}^{2} \mathrm{~s}^{-1}$ ) [21,22], so that the input flux of ${ }^{137} \mathrm{Cs}$ from surface to bottom was $1.41 \mathrm{~Bq} \mathrm{~m}^{-2} \mathrm{~d}^{-1}\left(0.98-2.07 \mathrm{~Bq} \mathrm{~m}^{-2} \mathrm{~d}^{-1}\right)$. In order to assess the mixing time of ${ }^{137} \mathrm{Cs}$ from surface to bottom, the residence time of ${ }^{137} \mathrm{Cs}$ was calculated by inventory and input flux as $66 \mathrm{~d}(45-95 \mathrm{~d})$, which is consistent with the residence time of ${ }^{210} \mathrm{~Pb}$ and ${ }^{210} \mathrm{Po}(\sim 60 \mathrm{~d})$ in the ECS [23].

(ii) Atmospheric input flux of ${ }^{137} \mathrm{Cs}$. The ${ }^{137} \mathrm{Cs}$ activities in seawater are barely seen in the time-series record of the China Seas, and so we have no ${ }^{137} \mathrm{Cs}$ benchmark level prior to the Fukushima nuclear accident. Therefore, in order to obtain the ${ }^{137} \mathrm{Cs}$ benchmark level, we set a hypothesis that the distribution of ${ }^{137} \mathrm{Cs}$ keeps constant with depth in the marginal sea if there is no additional ${ }^{137} \mathrm{Cs}$ source input. We then analyzed the vertical profile of ${ }^{137} \mathrm{Cs}$ in different marginal seas in the upper $200 \mathrm{~m}$ to test the hypothesis. For example, the ${ }^{137} \mathrm{Cs}$ activities of the upper $200 \mathrm{~m}$ water depth in the Japan Sea are $3.3-3.6 \mathrm{mBq} \mathrm{kg}^{-1}$ and vertical profiles are essentially constant with depth [24]. The ${ }^{137} \mathrm{Cs}$ activities have similar ranges $\left(2.2 \pm 0.2 \mathrm{~Bq} \mathrm{~m}^{-3}\right)$ in the Shimane, Fukui, Ishikawa and Niigata of the southern Japan Seas in their upper $200 \mathrm{~m} \mathrm{[25]} \mathrm{and} \mathrm{the} \mathrm{same} \mathrm{is} \mathrm{true} \mathrm{for} \mathrm{other} \mathrm{Asian}$ Oceans (Center North Pacific Ocean, Japan Seas, ECS, YS) [26]. Thus, knowing that the average depth and residence time of the ECS are only $72 \mathrm{~m}$ and 66 days, respectively, we believed that the ${ }^{137} \mathrm{Cs}$ activities in the seawater are identical both in surface and bottom water prior to the Fukushima accident; and the ${ }^{137} \mathrm{Cs}$ activity of $0.84 \mathrm{~Bq} \mathrm{~m}^{-3}$ in the bottom

Table 2 Estimated ${ }^{137} \mathrm{Cs}$ inventories of the seawater column in the East China Sea

\begin{tabular}{lccc}
\hline Station & Depth $(\mathrm{m})$ & $\begin{array}{c}{ }^{137} \mathrm{Cs} \mathrm{inventories}^{-2} \\
\left(\mathrm{~Bq} \mathrm{~m}^{-2}\right)\end{array}$ & Reference \\
\hline DH23 & 77 & 93 & This study \\
CB17 & 71 & 227 & \\
CB15 & 96 & 275 & \\
CB23 & 57 & 170 & \\
CB29 & 40 & 131 & \\
CB34 & 37 & 131 & \\
CB42 & 42 & 189 & \\
CB11 & 2280 & 3288 & \\
\hline
\end{tabular}

of station DH23 was considered as the background level for ${ }^{137}$ Cs activity before the occurrence of the Fukushima accident. This was consistent with the ${ }^{137} \mathrm{Cs}$ average activities of nearshore seawater $\left(0.9 \mathrm{~Bq} \mathrm{~m}^{-3}\right)$ in the ECS during 19952009 [27]. Furthermore, if a seawater volume of $4.5 \times 10^{4} \mathrm{~km}^{3}$ was applied for the ECS [28], the ${ }^{137}$ Cs amounts prior to the Fukushima accident could be estimated as $3.78 \times 10^{13} \mathrm{~Bq}$.

Atmospheric input flux of ${ }^{137} \mathrm{Cs}$ contains both dry and wet deposition, i.e.

$$
F_{\mathrm{t}}=F_{\mathrm{d}}+F_{\mathrm{w}},
$$

where $F_{\mathrm{t}}, F_{\mathrm{d}}$ and $F_{\mathrm{w}}$ represent the total input flux, the dry deposition flux and the wet deposition flux (all are in $\mathrm{Bq}$ $\mathrm{m}^{-2} \mathrm{~d}^{-1}$ ), respectively; and $F_{\mathrm{d}}$ and $F_{\mathrm{w}}$ could be calculated using the following equations:

$$
\begin{gathered}
F_{\mathrm{d}}=C_{\mathrm{a}} \cdot V_{\mathrm{d}}, \\
F_{\mathrm{w}}=P \cdot S \cdot C_{\mathrm{a}} / \rho_{0},
\end{gathered}
$$

where $C_{\mathrm{a}}$ is the ${ }^{137} \mathrm{Cs}$ activity in the atmosphere $\left(\mathrm{mBq} \mathrm{m}^{-3}\right)$, $V_{\mathrm{d}}$ is the dry deposition velocity $\left(\mathrm{cm} \mathrm{s}^{-1}\right), P$ is precipitation $\left(\mathrm{mm} \mathrm{d}^{-1}\right), S$ is the erosion factor in wet deposition $\left(\mathrm{g} \mathrm{m}^{-3}\right)$, and $\rho_{0}$ is the density of atmosphere $\left(1200 \mathrm{~g} \mathrm{~m}^{-3}\right)$.

It is essential to determine the $C_{\mathrm{a}}$ and $V_{\mathrm{d}}$ values in order to calculate the dry deposition flux. The $C_{\mathrm{a}}$ value of ${ }^{137} \mathrm{Cs}$ was $0.1241 \mathrm{mBq} \mathrm{m}^{-3}$, which was the average of the ${ }^{137} \mathrm{Cs}$ activities in the atmosphere monitored at PCY during 25 March to 23 April, 2011 [7]. We obtained the $V_{\mathrm{d}}$ value of ${ }^{137} \mathrm{Cs}$ by analogy: ${ }^{137} \mathrm{Cs}$ in the atmosphere mainly adheres to $1 \mu \mathrm{m}$ particles and its gathered distribution pattern is similar to that of $\mathrm{SO}_{4}^{2-}$ and $\mathrm{NH}_{4}^{+}$[29]; Shi et al. [30] further confirm that the $\mathrm{SO}_{4}^{2-}$ and $\mathrm{NH}_{4}^{+}$in aerosols are caught by $0.65-1.10$ $\mu \mathrm{m}$ fine particles in the ECS; and the dry deposition rate for $\mathrm{SO}_{4}^{2-}$ and $\mathrm{NH}_{4}^{+}$is $0.1-0.4 \mathrm{~cm} \mathrm{~s}^{-1}$ [31] and $0.05-0.2 \mathrm{~cm} \mathrm{~s}^{-1}$ [32-34], respectively. In our study, considering the estimates with a certain amount of variability, we adopted the lower limit of $\mathrm{NH}_{4}^{+}$and the upper limit of $\mathrm{SO}_{4}^{2-}$ as the ranges for ${ }^{137} \mathrm{Cs}$, while the average dry deposition rate for ${ }^{137} \mathrm{Cs}$ was derived from the average of the upper limit of $\mathrm{SO}_{4}^{2-}$ and $\mathrm{NH}_{4}^{+}$. Thus, the dry deposition rate of ${ }^{137} \mathrm{Cs}$ was $0.3 \mathrm{~cm} \mathrm{~s}^{-1}$ (0.05-0.4 $\left.\mathrm{cm} \mathrm{s}^{-1}\right)$ and we further calculated the dry deposition flux $\left(F_{\mathrm{d}}\right)$ as $32.2 \mathrm{mBq} \mathrm{m}^{-2} \mathrm{~d}^{-1}\left(5.4-42.9 \mathrm{mBq} \mathrm{m}^{-2} \mathrm{~d}^{-1}\right)$.

The wet deposition flux can be calculated if the precipitation $(P)$ and erosion factor $(S)$ are known. Precipitation in the China Seas has an obvious seasonal and inter-annual variability. The mean precipitation in spring in the ECS ranges from 100 to $170 \mathrm{~mm} / \mathrm{month}$ [35-38] and $170 \mathrm{~mm} /$ month was used in our study for the maximum estimate. $S$ is related to the dimension and physicochemical properties of fine particles and Duce et al. [32] indicate that the $S$ value of $\mathrm{NH}_{4}^{+}$ranges from 160 to $340 \mathrm{~g} \mathrm{~m}^{-3}$. In our study we adopted an $S$ value of $200 \mathrm{~g} \mathrm{~m}^{-3}$, which is consistent with that generally used for accumulation mode aerosols. The wet deposition flux of ${ }^{137} \mathrm{Cs}\left(F_{\mathrm{w}}\right)$ was calculated as $0.1172 \times 10^{-3}$ 
$\mathrm{mBq} \mathrm{m} \mathrm{m}^{-2} \mathrm{~d}^{-1}$. This wet deposition flux might be negligible in comparison with dry deposition. Thus, the total input flux of ${ }^{137} \mathrm{Cs}$ calculated was $32.2 \mathrm{mBq} \mathrm{m}^{-2} \mathrm{~d}^{-1}(5.4-42.9 \mathrm{mBq}$ $\mathrm{m}^{-2} \mathrm{~d}^{-1}$ ), and the amount of atmospheric input of ${ }^{137} \mathrm{Cs}$ was further calculated as $1.89 \times 10^{12} \mathrm{~Bq}$ during 25 March -8 June, 2011, which is only $4.7 \%$ of the total amount calculated for ECS. Therefore, based on the level of anthropogenic radioactive nuclide ${ }^{137} \mathrm{Cs}$, we suggested that the impact of the Fukushima nuclear accident on the ECS was minute.

Since ${ }^{134} \mathrm{Cs}$ has chemical properties similar to those of ${ }^{137} \mathrm{Cs}$, we also calculated the atmospheric input flux of ${ }^{134} \mathrm{Cs}$ using the identical hypothesis and methods. The result showed that the input flux and total amounts were $25.5 \mathrm{mBq} \mathrm{m}^{-2} \mathrm{~d}^{-1}$ and $1.49 \times 10^{12} \mathrm{~Bq}$, respectively, and as such, the ${ }^{134} \mathrm{Cs} /{ }^{137} \mathrm{Cs}$ ratio was close to 1 , clearly indicating a Fukushima nuclear power plant (NPP) source [39]. However, we noted only ${ }^{137} \mathrm{Cs}$, and ${ }^{134} \mathrm{Cs}$ was undetectable in the China Seas, implying that ${ }^{134} \mathrm{Cs}$ activity might have been below its detection limit. We therefore present our hypothesis that the ${ }^{134} \mathrm{Cs}$ and ${ }^{137} \mathrm{Cs}$ activities in the ECS were 0 and $0.84 \mathrm{~Bq} \mathrm{~m}^{-3}$, respectively, prior to the NPP accident at Fukushima. After the accident, the ${ }^{134} \mathrm{Cs}$ activity was still close to $0 \mathrm{~Bq} \mathrm{~m}^{-3}$, whereas the ${ }^{137} \mathrm{Cs}$ activity was slightly increased. According to the definition and computational formula for the detection limit [40-42], we calculated the detection limit of ${ }^{134} \mathrm{Cs}$ as $0.05 \mathrm{~Bq} \mathrm{~m}^{-3}\left(0.03-0.09 \mathrm{~Bq} \mathrm{~m}^{-3}\right)$ in the ECS, whereas the ${ }^{134} \mathrm{Cs}$ upper limit of activity in the ECS seawater through atmospheric input was also calculated as $\sim 0.03 \mathrm{~Bq} \mathrm{~m}^{-3}$, which was below the instrument detection limit and so ${ }^{134} \mathrm{Cs}$ was not detectable. Thus, the impacts of the Fukushima nuclear accident on the ECS were again minute.

(iii) Comparison with the Chernobyl nuclear accident. A comparison can be made, not just to current ${ }^{137} \mathrm{Cs}$ levels in the China Seas, but also to those measured immediately following the Chernobyl nuclear accident in 1986. After the Chernobyl accident, the ${ }^{137} \mathrm{Cs}$ activities of surface seawater were $4.56 \pm 0.29 \mathrm{~Bq} \mathrm{~m}^{-3}$ in the YS, 2.54 $\pm 0.28-3.30 \pm 0.25$ $\mathrm{Bq} \mathrm{m}^{-3}$ in the ECS [9] and 2.59 $\pm 0.09-2.83 \pm 0.08 \mathrm{~Bq} \mathrm{~m}^{-3}$ $\mathrm{Bq} \mathrm{m}{ }^{-3}$ in the SCS [10]. Whereas, after the Fukushima accident, the ${ }^{137} \mathrm{Cs}$ activities in surface seawater were obviously lower compared to those after the Chernobyl accident. With respect to the China Seas, the impact of Chernobyl thus exceeded that of Fukushima if measured by the changes in ${ }^{137} \mathrm{Cs}$ activities in the surface water.

(iv) Comparison of the Fukushima effects in the China Seas and those on the Northern Sanriku and Tsugaru Straits. We also compared the spatial difference in ${ }^{137} \mathrm{Cs}$ activities between China Seas and Japan Seas after the Fukushima nuclear accident. The Fukushima Daiichi Power Plant site (direct discharge) and Northern Sanriku and Tsugaru Straits (atmospheric fallout) were chosen to compare with the China Seas. The levels at the Fukushima discharge point were exceedingly high, with a peak of ${ }^{137} \mathrm{Cs} 6.8 \times 10^{7} \mathrm{~Bq} \mathrm{~m}^{-3}$ on 6 April, 2011, and the levels of ${ }^{137}$ Cs $30 \mathrm{~km}$ off Fukushima were also some 3-4 orders of magnitude higher than those which existed prior to the NPP accident [3]. This suggested that the direct discharge of radioactive materials from Fukushima nuclear accident to the ocean remarkably increased the ${ }^{137} \mathrm{Cs}$ activities.

An additional comparison can be made between the ${ }^{137} \mathrm{Cs}$ activities in the Northern Sanriku and the Tsugaru Straits with those in the China Seas. The elevated atmospheric fallout is assumed to be the main cause of the enhanced ${ }^{137} \mathrm{Cs}$ in the Northern Sanriku and Tsugaru Straits which are $250-450 \mathrm{~km}$ off Fukushima [2], and where the ${ }^{137} \mathrm{Cs}$ activities in surface seawater ranged from $1.9 \pm 0.1$ to $3.9 \pm 0.2 \mathrm{~Bq}$ $\mathrm{m}^{-3}$ in the Tsugaru Strait during 11 May to 19 June, 2011, which is higher than that which existed prior to the Fukushima accident $\left(1.4 \pm 0.1-1.8 \pm 0.1 \mathrm{~Bq} \mathrm{~m}^{-3}\right)$ [43]. In comparison with the China Seas, levels of ${ }^{137} \mathrm{Cs}$ in Northern Sanriku and Tsugaru Straits are 2 times higher than those during May-June, 2011. This should not be surprising since fallout deposition in general decreases with distance from the $\mathrm{Fu}$ kushima NPP, which is located more than $950 \mathrm{~km}$ from the China Seas. Thus the impact of ${ }^{137} \mathrm{Cs}$ derived from atmospheric fallout in the China Seas would be much smaller than that in Northern Sanriku and Tsugaru Straits.

\section{Conclusion}

We first presented the ${ }^{137} \mathrm{Cs}$ activity levels and distribution in the China Seas due to atmospheric fallout associated with the Fukushima nuclear accident. ${ }^{137} \mathrm{Cs}$ activities in seawater ranged from $0.75 \pm 0.07$ to $1.43 \pm 0.08 \mathrm{~Bq} \mathrm{~m}^{-3}$ with a mean value of $1.12 \pm 0.08 \mathrm{~Bq} \mathrm{~m}^{-3}$ in the China Seas during our observation period. The average inventory and atmospheric deposition flux of ${ }^{137} \mathrm{Cs}$ in the ECS were estimated to be 93 $\mathrm{Bq} \mathrm{m}^{-2}$ and $32.2 \mathrm{mBq} \mathrm{m}^{-2} \mathrm{~d}^{-1}\left(5.4-42.9 \mathrm{mBq} \mathrm{m}^{-2} \mathrm{~d}^{-1}\right)$, respectively, and the residence time of ${ }^{137} \mathrm{Cs}$ in the upper water column was further calculated as $66 \mathrm{~d}$ (45-95 d). It is important to note that these estimates have some uncertainty due to the limited field data. ${ }^{137} \mathrm{Cs}$ activities initially increased from the nearshore to the inner shelf, and subsequently decreased from the inner shelf to the outer shelf. Vertical profiles from the ECS showed higher ${ }^{137} \mathrm{Cs}$ activities at the surface, but lower activities at depth, further suggesting atmospheric input of ${ }^{137} \mathrm{Cs}$. The distribution pattern of ${ }^{137} \mathrm{Cs}$ in the region was presumably determined by a combination of the atmospheric deposition and subsequent mixing between different water masses such as the coastal currents, the Yangtze River plume and the Taiwan Warm Currents. Finally, we concluded that, by comparing the ${ }^{137} \mathrm{Cs}$ activities and inventory at different spatial and temporal scales in terms of ${ }^{137} \mathrm{Cs}$, the ECS was little impacted by the Fukushima accident and, indeed, the amount of ${ }^{137} \mathrm{Cs}$ released into the ECS from the Fukushima accident was minute. 
This work was supported by the National Basic Research Program of China (2009CB421200). The authors express their gratitude to J W Liu, Z Y Wang, Z P Jiang and S Y Huang for their help with sample collection and to $J \mathrm{H} \mathrm{He}, \mathrm{W}$ Men and Dr. M Aoyama for their help with sample measurement. The authors are also indebted to Dr. S Kandasamy for his constructive comments, and to $Q$ Liu for helpful discussion. The authors are also grateful to Dr. ZL Liu for providing temperature and salinity data and the crew of Dong Fanghong II for providing much help during the cruise. The authors thank the two anonymous reviewers' constructive comments on the paper. Professor John Hodgkiss is thanked for polishing the English.

1 Qiao F L, Wang G S, Zhao W, et al. Predicting the spread of nuclear radiation from the damaged Fukushima Nuclear Power Plant. Chin Sci Bull, 2011, 56: 1890-1896

2 Tsumune D, Tsubono T, Aoyama M, et al. Distribution of oceanic ${ }^{137}$ Cs from the Fukushima Daiichi Nuclear Power Plant simulated numerically by a regional ocean model. J Environ Radioact, 2012, 111: $100-108$

3 Buesseler K O, Jayne S R, Fisher N S, et al. Fukushima-derived radionuclides in the ocean and biota off Japan. Proc Natl Acad Sci USA, 2012, 109: 5984-5988

4 Chino M, Nakayama H, Nagai H, et al. Preliminary estimation of release amount of ${ }^{131} \mathrm{I}$ and ${ }^{137} \mathrm{Cs}$ accidentally discharged from the $\mathrm{Fu}$ kushima Daiichi Nuclear Power Plant into the atmosphere. J Nucl Sci Technol, 2011, 48: 1129-1134

5 Bowyer T W, Biegalski S R, Cooper M, et al. Elevated radioxenon detected remotely following the Fukushima nuclear accident. J Environ Radioact, 2011, 102: 681-687

6 Manolopoulou M, Vagena E, Syoulos S, et al. Radioiodine and radiocesium in Thessaloniki, Greece due to the Fukushima nuclear accident. J Environ Radioact, 2011, 102: 796-797

7 Huh C A, Hsu S C, Lin C Y. Fukushima-derived fission nuclides monitored around Taiwan: Free tropospheric versus boundary layer transport. Earth Planet Sci Lett, 2012, 319-320: 9-14

8 Aoyama M, Hirose K, Miyao T, et al. Low level ${ }^{137} \mathrm{Cs}$ measurements in deep seawater samples. Appl Radiat Isot, 2000, 53: 159-162

9 Nagaya Y, Nakamura K. ${ }^{239,240} \mathrm{Pu}$ and ${ }^{137} \mathrm{Cs}$ in the East China and the Yellow Seas. J Oceanogr, 1992, 48: 23-25

10 Yamada M, Zheng J, Wang Z L. ${ }^{137} \mathrm{Cs}$, ${ }^{239+240} \mathrm{Pu}$ and ${ }^{240} \mathrm{Pu} /{ }^{239} \mathrm{Pu}$ atom ratios in the surface waters of the western North Pacific Ocean, eastern Indian Ocean and their adjacent seas. Sci Total Environ, 2006, 366: 242-252

11 Ito $\mathrm{T}$, Povinec $\mathrm{P} \mathrm{P}$, Togawa $\mathrm{O}$, et al. Temporal and spatial variations of anthropogenic radionuclides in Japan Sea waters. Deep-Sea Res II, 2003, 50: 2701-2711

12 Ikeuchi Y, Amano H, Aoyama M, et al. Anthropogenic radionuclides in seawater of the Far Eastern Seas. Sci Total Environ, 1999, 237-238: 203-212

13 UNSCEAR. Sources and Effects of Ionizing Radiation. New York: United Nations, 1993

14 Hsu S C, Huh C A, Chan C Y, et al. Hemispheric dispersion of radioactive plume laced with fission nuclides from the Fukushima nuclear event. Geophys Res Lett, 2012, 39: 1-6

15 Chen C T A. Chemical and physical fronts in the Bohai, Yellow and East China seas. J Marine Syst, 2009, 78: 394-410

16 Nagaya Y, Nakamura K. Artificial radionuclides in the western Northwest Pacific (I): ${ }^{90} \mathrm{Sr}$ and ${ }^{137} \mathrm{Cs}$ in the deep waters. J Oceanogr Soc Jpn, 1981, 37: 135-144

17 Nagaya Y, Nakamura K. ${ }^{239,240} \mathrm{Pu},{ }^{137} \mathrm{Cs}$ and ${ }^{90} \mathrm{Sr}$ in the central North Pacific. J Oceanogr Soc Jpn, 1984, 40: 416-424

18 Nagaya $Y$, Nakamura K. Artificial radionuclides in the western Northwest Pacific (II): ${ }^{137} \mathrm{Cs}$ and ${ }^{239,240} \mathrm{Pu}$ inventories in water and sediment column observed from 1980 to 1986. J Oceanogr Soc Jpn, 1987, 43: 345-355
19 Ito T, Aramaki T, Kitamura T, et al. Anthropogenic radionuclides in the Japan Sea: Their distributions and transport processes. J Environ Radioact, 2003, 68: 249-267

20 Hirose K, Sugimura Y, Aoyama M. Plutonium and ${ }^{137}$ Cs in the Western North Pacific: Estimation of residence time of plutonium in surface water. Appl Radiat Isot, 1992, 43: 349-359

21 Liu G S, Men W, Ji L H. Vertical mixing rate evaluation based on radium isotope distributions of Yellow Sea and East China Sea (in Chinese). Chin J Geophys, 2010, 53: 1976-1984

22 Men W, Liu G S, Chen M, et al. ${ }^{224} \mathrm{Ra}$ in the seawater of the East China Sea (in Chinese). J Chin Univ Geosci, 2011, 36: 999-1008

23 Nozaki Y, Tsubota H, Kasemsupaya V, et al. Residence times of surface water and particle-reactive ${ }^{210} \mathrm{~Pb}$ and ${ }^{210} \mathrm{Po}$ in the East China and Yellow seas. Geochim Cosmochim Acta, 1991, 55: 1265-1272

24 Hirose K, Amano H, Baxter M S, et al. Anthropogenic radionuclides in seawater in the East Sea/Japan Sea: Results of the first-stage Japanese-Korean-Russian expedition. J Environ Radioact, 1999, 43: 1-13

25 Kasamatsu F, Inatomi N. Effective environmental half-lives of ${ }^{90} \mathrm{Sr}$ and ${ }^{137} \mathrm{Cs}$ in the coastal seawater of Japan. J Geophys Res, 1998, 103: 1209-1217

26 Duran E B, Povinec P P, Fowler S W, et al. ${ }^{137} \mathrm{Cs}$ and ${ }^{239+240} \mathrm{Pu}$ levels in the Asia-Pacific regional seas. J Environ Radioact, 2004, 76: 139-160

27 Yao H Y, Zhu L, Zhou Y, et al. Monitoring of radioactivity levels of sea water in near coast marine environment in china during 19952009 (in Chinese). Radiat Prot Bull, 2010, 30: 13-17

28 Chen C T A. The Kuroshio intermediate water is the major source of nutrients on the East China Sea continental shelf. Oceanol Acta, 1996, 19: 523-527

29 Jost D T, Gaggeler H W, Balternperger U, et al. Chernobyl fallout in size-fractionated aerosol. Nature, 1986, 324: 22-23

30 Shi J H, Zhang Y, Gao H W, et al. Characteristics and sources of atmospheric aerosols over the East China Sea (in Chinese). J Environ Sci-Chin, 2011, 31: 1750-1757

31 Gao H W, Huang M Y, Guan Y P, et al. Dry deposition model for sulfur pollutants (in Chinese). Environ Sci, 1997, 18: 1-4

32 Duce R A, Liss P S, Merrill J T, et al. The atmospheric input of trace species to the world ocean. Glob Biogeochem Cycle, 1991, 5: 193-259

33 Carbo P, Krom M D, Homoky W B, et al. Impact of atmospheric deposition on $\mathrm{N}$ and $\mathrm{P}$ geochemistry in the southeastern Levantine basin. Deep-Sea Res, 2005, 52: 3041-3053

34 Spokes L J, Jickells T D. Is the atmosphere really an important source of reactive nitrogen to coastal waters. Cont Shelf Res, 2005, 25: 2022-2035

35 Liu Y, Zhou M Y. Atmospheric input of aerosols to the eastern seas of China (in Chinese). Acta Oceanol Sin, 1999, 21: 38-45

36 Wan X F, Wu Z M, Chang Z Q, et al. Reanalysis of atmospheric flux of nutrients to the South Yellow Sea and the East China Sea (in Chinese). Mar Environ Sci, 2002, 21: 14-18

37 Zhu Y M, Liu S M. Nutrients in atmospheric wet deposition in the East China Sea (in Chinese). Environ Sci, 2011, 32: 2724-2731

38 Chou M D, Wu C H, Kan W S. Large-scale control of summer precipitation in Taiwan. J Clim, 2011, 24: 5081-5092

39 Buesseler K O, Aoyama M, Fukasawa M. Impacts of the Fukushima nuclear power plants on marine radioactivity. Environ Sci Technol, 2011, 45: 9931-9935

40 Currie L A. Limits for qualitative detection and quantitative determination. Anal Chem, 1968, 40: 586-593

41 Zvara I, Povinec P, Sykora I. Determination of very low levels of radioactivity. Pure Appl Chem, 1994, 66: 2537-2586

42 Liu G S, Yang W F, Jia C X, et al. Rapid concentration in-situ and $\gamma$ spectrum analysis of radium isotopes in large volume seawater (in Chinese). Nucl Tech, 2004, 27: 116-121

43 Inoue M, Kofuji H, Hamajima Y, et al. ${ }^{134} \mathrm{Cs}$ and ${ }^{137} \mathrm{Cs}$ activities in coastal seawater along Northern Sanriku and Tsugaru Strait, northeastern Japan, after Fukushima Dai-ichi Nuclear Power Plant accident. J Environ Radioact, 2012, 111: 116-119

Open Access This article is distributed under the terms of the Creative Commons Attribution License which permits any use, distribution, and reproduction in any medium, provided the original author(s) and source are credited. 